\title{
World War II and the Issue of Refugeeism Focusing on the Diocese of České Budějovice in Light of Archive Materials from the Episcopal Archive
}

\section{Martin Weis}

\section{Introduction}

Regarding the present refugee crisis which the continent of Europe is undergoing, it is frequently said that it is the greatest refugee crisis since the end of World War II. On World War II itself a great number of monographs and academic studies have already been written in connection with expelling inhabitants and refugeeism; a great number of different statistical data exists, etc. In this study I intend to recall the issue of refugeeism associated with this tragic segment of human history from a specific point of view. I will show refugeeism to be part of the history of the diocese of České Budějovice in 1938-1947, especially in light of archive materials from the episcopal archive. I will engage authentic documents to show how the fervent issue of refugeeism was perceived and frequently personally experienced by Catholic clergymen of the time.

\section{On the literature and sources}

On the issue of refugeeism in 1938-1947 focusing on the diocese of České Budějovice only a few monographs and studies have been published, which bear upon the present topic only tangentially or in a narrow, limited way. ${ }^{1}$ That is why the most valuable source of information on the

1 Czech Church history of 1938 to 1947 is contained, e.g. in the monograph Jaroslav POLC, Stručnýpřehled dějin českých a moravských diecézí po tricetileté válce, Praha: KTF UK, 1995. The issue of the expulsion of Czech priests from their places of work by the Nazi regime and their subsequent persecution is dealt with, e.g. by the monograph Josef BENEŠ, Kaine, kde je tvůj bratr, Praha: ČKCH, 1971; the fates of Sudetenland German priests is documented by the monograph Emil VALASEK, Der Kampf gegen die Priester im Sudetenland 1938 bis 1945. Eine Dokumentation, Königstein: Institut für Kirchengeschichte von Böhmen - Mähren - Schlesien, 2003. It is also necessary to mention the monograph capturing the fates of Sudetenland Catholics priests and lay in confrontation with the Nazi regime: Rudolf GRULICH, Sudetoněmečtí katolíci jako oběti nacismu, Praha: HTF UK, 2002. On the more general issue of cohabitation of Czechs and Germans it is possible to recommend, e.g. the monograph Josef ŠKRÁBEK, Včerejši strach. Jaké to bylo mezi Čechy a Němci?, Praha: Vyšehrad, 2002; or the monograph Milan SLÁDEK, Němci v Čechách, Praha: Pragma, 2002. The issue of so-called wild expulsions in 1945 with focus on the South Bohemian region is presented, e.g. by the monograph Josef MLYNÁRIK, Tragédie Vitorazska 1945-1953. Poprava v Tušti, Třeboň: Carpio, 2005. Studies published in the journal Archiv für Kirchengeschichte von Böhmen - Mähren - Schlesien, also have bearing on the issue, namely in the seventh volume published in 1985 with the title Festschrift zur zweiten Säkularfeier des Bistum Budweis in Böhmen 1785-1985. Here it is necessary to mention especially the studies Rudolf PALECZEK, Die deutschen Budweiser Diözesanen nach 1945; and Rudolf PALECZEK, Die kirchliche Administration des deutschen Anteils der Diözese Budweis 1938-1946. We also draw attention to the studies Martin WEIS, Der Weg von der Diktatur des Nationalsozialismus zu den Dekreten des Präsidenten Benesch. Ein Blick in die Geschichte der katholischen Kirche in Südböhmen, HLK - Neue Folge 91/2007, pp. 439-450; Martin WEIS, Hohenfurther Stift in den Jahren 1945-1948, HLK - Neue Folge 92/2008, pp. 35-42; Martin WEIS, Proměny soužití českého a německého obyvatelstva na Šumavě v letech 1898-1938. Sonda do každodennosti 
present issue is supplied by the episcopal archive, deposited in the State Regional Archive in Třebonn. ${ }^{2}$ Printed archive materials such as the diocesan catalogue, ${ }^{3}$ official bulletins ${ }^{4}$ or occasional instructions of the state administration were also not left aside.

\section{Refugeeism as a result of the Munich Agreement and the annexation of the bor- derlands by Germany in 1938}

It must be emphasized that streams of refugees were already headed for Czechoslovakia, many years before 1938. The first great refugee wave had been caused by the terror of the Bolshevik regime in Russia. When the White armies and their allies had been defeated and the refugeestaying in camps in the Balkans began to see that they will not be able to return to their homeland, they looked for countries where they could settle and find employment. One of the countries thatopened themselves up wide to this refugee wave was the Czechoslovak Republic. As part of the so-called 'Russian Aid Action', according to a decree of $28^{\text {th }}$ July 1921, aid to Russian refugees was established in Czechoslovakia under the patronage of the Foreign Ministry, which was financed by the state budget. So in the period between WWI and WWII a large number of Russian refugees settled down in this country, who found refuge here especially thanks to the initiatives of President T. G. Masaryk. Historians claim that Czechoslovakia allegedly spent more to support Russian refugees than all other European states together - the sum of almost half a billion Czechoslovak crowns is cited. It certainly was not a pure altruism that was motivated by the Russophilia of the then President Masaryk, who much admired Russian culture and the spiritual life of pre-war Russia. Of course, 'in return' the Russian refugees, especially the professionals and academics, were to take part in the industrial and scientific development of the young Czechoslovak Republic. Allegedly a number of top Russian experts began to lecture at Czech universities, work on editorial boards of journals as high quality journalists, etc. ${ }^{5}$

Another wave of refugees to Czechoslovakia was brought about by Adolf Hitler's National Socialism's rise to power in Germany. These were German and later also Austrian citizens, especially those of a leftist orientation, communist party or social democratic party members and also Jewish refugees. But these mostly did not find permanent refuge in Czechoslovakia and were forced to seek paths to further emigration. ${ }^{6}$

In 1938 the situation in Central Europe changed radically. On $11^{\text {th }}$ March 1938 a political coup took place in Austria and on the following day, at the request of local supporters of Adolf Hitler, the German army entered Austria. Adolf Hitler then annexed the Austrian lands to the German Reich, which was formally confirmed by the popular referendum held on $10^{\text {th }}$ April 1939.7 Perse-

farních společenství ve světle materiálů biskupského archivu, Auspicia 2/2007, pp. 31-36; and Martin WEIS, Osudy katolické církve na jihu Čech v období Protektorátu Čechy a Morava, Studia theologica 1/1999, pp. 63-70.

2 State Regional Archive in Třeboň (further only SRA Třeboň), fond Episcopal Archive (further EA), years 1938-1947, especially archivalia from folders labelled registry 1903-1945 and persecution during the war.

3 Catalogus saecularis et regularis cleri dioeceseos Bohemo-Budvicensis, 1938, 1939, 1940 and 1948.

4 Acta curiae episcopalis Bohemo Budvicensis (further ACEB) of 1938-1947.

5 In 1922-1928 there were allegedly over 25,000 such refugees. Cf. Anastasie KOPŘIVOVÁ, Osudy ruské emigrace v Československu, Pamét a dějiny 2/2015, pp. 27-50. On this issue it is also possible to consult the book Ljubov BĚLOŠEVSKÁ (ed.), Kronika kulturního, vědeckého a společenského života ruské emigrace v Československu I, 1919-1929, Praha: Slovanský ústav AV ČR, 2000; or Světlana TEJCHMANOVÁ, Rusko v Československu: Bílá emigrace v ČSR 1917-1939, Praha Jinočany: H \& H, 1993.

6 On this topic it is possible to recommend the erudite monograph Kateřina ČAPKOVÁ and Michal FRANKL, Nejisté útočiště. Československo a uprchlíci pred nacismem 1933-1938, Praha and Litomyšl: Paseka, 2008.

7 On this topic in more detail see, e.g. Heinz ARNBERGER (ed.), „Anschluß“ 1938. Eine Dokumentation, Wien: Österreichischer Bun- 
cution of leftist-minded inhabitants, persons of Jewish ancestry, as well as committed Christians came to be realized there as well according to the German Nazi model. ${ }^{8}$

Soon afterwards, in autumn 1938, Czechoslovakia was to become the next victim of the expansive German Nazism. The overall tense political situation is well documented by two reports from the official bulletin of the episcopal consistory. One is a very emphatic appeal of $29^{\text {th }}$ September 1938 in which spiritual administrators were ordered to use every opportunity from the pulpit or otherwise to admonish their parishioners to stay calm and sober, pray for their country and trust the government of the Czechoslovak Republic. ${ }^{9}$ The second instruction, already preparing the clergymen of the Roman Catholic Church for the possibility of evacuating the area affected by military conflict, instructs them to secure the registers, remove the more valuable liturgical objects and precious works of art to the interior or bury them in a secret place. ${ }^{10}$

The political crisis in international relations culminated on $30^{\text {th }}$ September 1938 by the sealing of the so-called Munich Agreement. As a consequence of that almost one third of the Czech lands were annexed by Germany. On $1^{\text {st }}-10^{\text {th }}$ October 1938 the German army occupied the Czech borderlands, whereby Southwest Bohemia was incorporated into Bavaria and South Bohemia into the Austrian district of Upper Danube. The Bishop of České Budějovice Šimon Bárta reacted to the newly arisen situation with a pastoral letter in which he mentions the bitter lot of refugees already in the introduction: 'A great disaster to the country and nation, the deep grief and sorrow which has taken grip of the hearts of us all as a result, the bitter lot of hundreds of thousands of our brothers and sisters and the melancholy worries concerning the future of our nation urge your arch-shepherd and father to speak a fatherly word to you'; and he emphatically admonishes the faithful of the diocese to solidarity with the refugees from our borderlands: 'among the tasks most at hand and an urgent duty is taking care of our neighbours who have recently suffered grave existential damage through loss of property, employment and home. ${ }^{11}$ In a similar spirit spoke the common pastoral letter signed by the Archbishop of Prague Cardinal Kašpar, the Archbishop of Olomouc Prečan, the Bishop of České Budějovice Bárta, the Bishop of Brno Kupka, the Bishop of Hradec Králové Pícha and the Bishop of Litoměřice Weber. Besides words of comfort and encouragement it also contains our ordinaries' appeal to selfless work and restraining oneself in order to help suffering neighbours, by appealing to the words of Scripture: 'Who has goods of this world and sees his brother suffering in need and closes his heart to him, how can love of God stay in him? Children, let us not love by word or tongue, but by deed and in truth, says the preacher of love St. John. By that you will also manifest your true patriotism.' ${ }^{12}$

desverlag, 1988; or the newer publication Werner WELZIG, Anschluss: März-April 1938 in Österreich, Wien: Verlag der Österreichischen Akademie der Wissenschaften, 2010. In the Czech language it is possible to consult the relevant passage in the monograph Václav VEBER, Dějiny Rakouska, Praha: Nakladatelství Lidové noviny, 2002, pp. 531-548.

8 Nazi church policy proceeded in several phases. The first phase, lasting approximately until 1935, was marked by looking for paths to peaceful cohabitation. In the same period the Concordat was signed between the Holy See and Germany. The Nazi regime welcomed the Concordat especially for reasons of foreign policy, as it intended to intensify cooperation with traditionally Catholic countries, such as Italy, Spain and Portugal. In the first phase of their church policy the Nazis were not proceeding openly against the Christian churches for tactical reasons, though they were covertly striving to gradually isolate them and exclude them from society. The second phase of Nazi Germany's church policy took place in 1936-1940 and was marked by already unconcealed effort to subordinate all churches to the totalitarian regime with the help of repressive measures. Pope Pius XI reacted to the newly arisen situation with the encyclical Mit brennender Sorge, in which he defended Christianity against the Nazi neo-paganism. Cf. František VAŠEK and Zdeněk ŠTĚPÁNEK, Trnitá cesta moravského duchovenstva (1939-1945), Brno: Šimon Ryšavý, 2003, p. 17n.

9 Cf. ACEB 1938, no. 9, p. 53.

10 Ibid, p. 54, Instructions for the case of territory evacuation.

11 Cf. ACEB 1938, no. 10, appendix pastoral letter dated October $23^{\text {rd }}, 1938$.

12 Cf. ACEB 1938, no. 11, appendix pastoral letter dated October $2^{\text {nd }}, 1938$. 
Many Catholic clergymen of the diocese of České Budějovice began to tackle a very important existential and moral question as to whether to join the stream of refugees and leave the parish entrusted to them, or stay and be exposed to the risk of persecution. This dilemma is well documented by the following letter written by the Catholic clergyman from the parish in Nermecký Rychnov near Frymburk: 'Since the times are grave and the future is impossible to predict, I ask for a kind reply whether I could leave the settlement entrusted to me in case, Lord God forbid, a clash between our state and the German state should occur in the future. The entire settlement is located along the border and as far as I know in case of a clash the inhabitants would be asked to leave the area, civil servants first. In such a case this region as far as the river Moldau would probably be sacrificed to obtain time for transporting our army and a number of buildings would be destroyed before the withdrawal. If this area was then to devolve to Germany, although recent events suggest that it will not occur, I beg that in such a case the most Reverend Consistory itself ask that I be handed over to the Czechoslovak Republic, as I would never want to serve under the Swastika. That in case I would not be allowed to ask myself. $23^{\text {rd }}$ July $1938 .{ }^{13}$ To this clergyman's pleading request the episcopal consistory of České Budějovice addressed the following reply entirely according to the usual norms of Catholic moral doctrine on the obligations of the spiritual administrator: 'To the query we reply: unless special instructions are issued to spiritual administrations, that which moral manuals teach on the obligations of spiritual shepherds holds. If the community of faithful stays, the spiritual shepherd must stay or take care that they are not left without spiritual administration. If evacuation takes place, whether by decree of state power or de facto, the spiritual shepherd goes with his flock. ${ }^{14}$

This letter was not isolated, as witnessed, e.g. by the request of the parish priest from Věžovatá Pláně asking what he was to do when the village had been occupied by the German army and the subsequent repeated request of an answer on the grounds that he must leave his parish for political and nationalist reasons: 'Most reverend episcopal consistory in České Budějovice! The one signed in deepest respect allows himself to report in respectful service that on $8^{\text {th }}$ October 1938 Pláně Věžovatá was annexed for the German Reich - by the army of the German Reich. For that reason the one signed in deepest respect begs for further gracious instructions. For lack of postal stamps he attaches a 5 Kč government stamp for a gracious answer by registered post. Parish office in Pláně Věžovatá on $8^{\text {th }}$ October 1938 Václav Jelínek, parish priest. ${ }^{15}$ When he had received no answer from České Budějovice he repeated his request as follows: 'Most reverend episcopal consistory in České Budějovice! Under number 308 of $8^{\text {th }}$ October of this year the one signed in deepest respect allowed himself to report that on that day Věžovatá Pláně was annexed by the German army for the German Reich and begged for gracious service instructions. As no communication has come so far, the one signed in deepest respect allows himself - assuming that the first letter had probably not been delivered, to report respectfully that he cannot stay here for health reasons as well and will come as soon as possible. Parish office in Pláně Věžovatá on $25^{\text {th }}$ October 1938 Václav Jelínek. ${ }^{16}$

In the same year a request for transfer in the consequence of changes in the state border is witnessed also by another letter found in the episcopal archive: 'To the most reverend episcopal

13 SRA Třeboň, fond EA, carton no. 958, signatura I - E - 4, registry 1903-1945, folder 1938, original letter, signed.

14 SRA Třeboň, fond EA, carton no. 958, signatura I - E - 4, registry 1903-1945, folder 1938, draft of reply of $26^{\text {th }}$ July 1938 , sent $27^{\text {th }}$ July 1938 , original unsigned.

15 Ibid, original letter, signed, without a draft of reply.

16 Ibid, original letter, signed, without a draft of reply. 
consistory in České Budějovice. The one signed in respect begs that a Czech parish in the interior be temporarily granted to me, because on $25^{\text {th }}$ October of this year there is to be a referendum here and the local inhabitants claim that they will all vote for the German Reich and will bear no Czech person or Czech parish priest here. So it is evident that in such circumstances I cannot stay here, otherwise I would be exposed to the greatest persecution and suffering. Pastoral care would be totally impossible here. I have been here for almost 22 years and have lived through much injustice and denunciation. All the documents accompanying the request are still at the most reverend episcopal consistory since February of this year. In Bukovec on $5^{\text {th }}$ October 1938, Josef Jačka, parish priest.'.17

The following letter witnesses to not only the complex refugee, national and political situation after the seizure of the South Bohemian borderlands, but also to an isolated priestly failure of a priest of German nationality, who in the spirit of the German National-Socialist propaganda embraced the 'swastika cult'. It is a letter of the parish office of Lažiště from $21^{\text {st }}$ December 1938 describing the truly desperate religious situation in the separated areas: 'Most reverend episcopal consistory in České Budějovice! (...) I further report that Kratusín has been annexed from the settlement - but please do not assign it to Záblatí, as long as the Reich allows the inhabitants of Kratusín to come here to church and me to go there to administer the last rites. All come to church to Lažiště and I go there to administer the last rites. Already three times since the annexation and each time the German officials let me through. On the annexation morning I read holy mass in the Kratusín chapel and it was the bleakest day of my life - an hour later they annexed them. And the inhabitants of Kratusín - of whom over the past seven years not even one omitted the holy sacraments in Lent - are desperate because the Záblatí lord did not want to pray with their children in the Czech school, helped to organize the Henleins and today has the holy cross decorated on each side with one (painted swastika) at home in the parish house. That is what I have been told by old Vojta, farmer from Kratušín, with his hand raised to an oath - and he stated: The Lord God must forgive us, we will die without a priest, if we have to depend on Záblatí. It is not my person, no. I begged them to forgive and they said that they are not angry, but they are Catholics and there is no longer the holy cross in Záblatí. It is there with the swastika. What am I to do? The Czech bordermen and faithful heads can do it, because they don't see the holy cross alone in Záblatí. I beg you, I am not reporting, and I would be unhappy if the Záblatí lord was more angry with them and with me. I only request that the parish jurisdiction be left to me as long as I can go with legal consent to Kratušín and a part of Záblatí, which is also annexed. A part of Chlístov were Germans, let them go to Záblatí. The money that is due to the rev. parish priest of Záblatí, let the inhabitants of Kratušín and others pay it to him. The children will also come here to school in the new year. I begged with my brother, the directing official here, that they let them. The German officials' reply was: Yes, until laws permit. I had a funeral from Kratušín, also here to Lažiště. - This week. Officials allowed it. Already the propaganda is working among the Czech Catholics. We believe in God like you do - we just don't want Jews, Christ, Mary, Joseph - that will pass. We want only God. (...) A bleak life, those in the interior have no idea. The youth have already been totally taken in. Ein Gott und Führer. The times will be worse for the Sudetenland than the post-coup time was for us. (...) In Lažiště, on $21^{\text {st }}$ December 1938 Josef Dušák, parish priest. ${ }^{18}$

17 Ibid, original letter, signed, without a draft of reply.

18 SRA Třeboň, fond EA, carton no. 958, signatura I - E - 4, registry 1903-1945, folder 1938, original letter of $21^{\text {st }}$ December 1938 , without a draft of reply. 
In the separated parts of the diocese there were 139 parishes, in which ca. 258,000 Catholics and 210 priests were living. Large transfers of Czech priests to the interior, whereby they themselves became refugees, is documented already in the November issue of the diocesan official bulletin in the section 'personalia'. Priests of German nationality were appointed to the empty places as administrators, whereby it is necessary to mention that there were fewer priests than parishes. Especially the poor mountain parishes of Šmava long remained vacant. ${ }^{19}$ In December 1939 the separated parishes were incorporated under the administration of the neighbouring dioceses in the German Reich. ${ }^{20}$

After the enforced breakup of Czechoslovakia and establishment of the Protectorate of Bohemia and Moravia the Nazis immediately began to realize their church policy in our territory, where it was directed by the Reichsprotektor's office. In this context it is necessary to take a closer look at the figure of the Deputy Reichsprotektor Reinhard Heydrich, who played a very important part in conceiving the Nazi church policy. Although he was brought up in the religious spirit, in 1936 he defected from the Catholic Church and fought against it sharply. The authors of the book The Thorny Path of Moravian Clergy mention a highly expressive characteristic of Heydrich: 'He reduced the enemies of Nazism to two spiritual and organizational spheres - Jews and political clergy. ${ }^{21}$ He regarded the Freemasons as a 'frontline organization' of international Jewry and in the Catholic Church he viewed the Jesuit Order similarly. Perhaps that is why already by the beginning of the war he considered sending the Jesuits to concentration camps in the East. On his arrival in Prague Heydrich became infamous amongst others for working out a plan for an infiltration of devoted Nazis into the Catholic Church. He intended to select suitable candidates from among the Hitlerjugend, whom he wanted to have study theology under false names. He seriously reckoned that in about fifteen years they could then occupy leading positions in the Catholic Church. He harboured similar plans for proceeding against the other Christian churches. A number of Catholic clergymen left the country and became involved in foreign resistance, while the ones at home organized pilgrimages which turned into anti-Nazi manifestations, and I must not omit the courageous patriotic sermons of many clergymen. In many cases the clergy's resistance against the Nazi regime broke out into direct involvement in domestic organized resistance, hiding weapons, illegal printed matter and persons persecuted by the regime. The Nazis' revenge was often very harsh and ended in execution or death by gas in a concentration camp.

One of the main reasons why priests were persecuted was, for example, the practice of the Nuremberg racial laws, since not even church employees were allowed to be of Jewish origin. All official bulletins of the diocese of České Budějovice from the Protectorate years always contain at least one page-long list of names for which an excerpt from the appropriate parish office registers had to be made concerning baptisms, weddings or deaths. Falsifying this information, which was to document the non-Jewish origin of the inquirer, was severely punished. Despite that there were many Catholic priests who issued such falsified documents and put their own lives at stake in

19 After the annexation of the borderlands in 1938, 32 Czech clergymen altogether left and 24 German clergymen were appointed in their place in territorio occupato, cf. ACEB 1938, no. 12, pp. 61-62. The January issue of the official bulletin of 1939 published a call for filling 65 vacant parish beneficia in territorio occupato, cf. ACEB 1939, no. 1, p. 5. But not all Czech clergymen left their places, e.g. the fearless parish priest in Klenčí P. Antonín Pospíšil, who after the annexation of the borderlands supported in all possible ways Czech national life in his parish, secretly taught religion in Czech at the parish house and smuggled Czech religious books from the Protectorate. He was arrested by the Gestapo on $27^{\text {th }}$ October 1944 and after harsh interrogations was sent to the concentration camp in Terezín. Cf. Josef BENEŠ, Kaine, kde je tvi̊j bratr, Praha: ČKCH, 1971, p. 253n.

20 Cf. Catalogus saecularis et regularis cleri dioeceseos Bohemo-Budvicensis, 1940, p. 140f.

21 Cf. František VAŠEK and Zdeněk ŠTĚPÁNEK, Trnitá cesta moravského duchovenstva (1939-1945), p. $17 f$. 
order to save numerous persons from being transported to Terezín or another concentrationcamp for the eradication of the Jewish race. Unfortunately, several individuals were found even among our nation who put themselves in the service of the occupying power as provocateurs and informers. The activity of such a provocateur cost also the life of one of the priests of the diocese of České Budějovice - P. František Vošta, dean in Opařany. He was ordained to the priesthood in 1907 and entered the spiritual administration as chaplain in Žirovnice u Počátek. Then he was administrator in Tannaberk and parish priest in Klenčí. In 1938 after the borderlands were annexed be became dean in Opařany near Tábor. In 1941 he fell into a trap set by the Gestapo. He issued false genealogical documents to a provocateur to establish non-Jewish origin, and even told him that he asks nothing as reward for that but that he remains an honest Czech and good Christian. P. Vošta's Calvary began on $30^{\text {th }}$ August 1941 by imprisonment and questioning by the Gestapo in Tábor and continued through Prague and Terezín to the concentration camp Dachau; P. Vošta's place and date of death is uncertain. The documents sent by the Gestapo state $26^{\text {th }}$ June 1942 as the date of death and heart stroke as the cause of death. According to Josef Beneš on $28^{\text {th }}$ May 1942, P. Vošta was included in a so-called disabled transport, which ended in a gas chamber. The urn with ashes sent from the concentration camp was placed at the cemetery in Dražice in the same year. ${ }^{22}$

Among priests investigated by the Gestapo and expelled from their place of activity I would like to commemorate here the figure of Tecelin Jaksch, O.Cist., abbot of the monastery in Vyšší Brod and Vicar General of the separated parishes of the diocese of České Budějovice. He was the first priest from the Sudetenland part of the diocese to be investigated by the Gestapo. He was arrested on $21^{\text {st }}$ November 1938 and investigated for over a month in Linz and Český Krumlov. When he was released he could not return to his monastery in Vyšší Brod and had to live in strict isolation throughout the duration of WWII in the monastery Porta Coeli near Tišnov. In 1948 he had to flee abroad from the ascending communist totality. ${ }^{23}$

Not only Czech priests of the diocese of České Budějovice were persecuted and jailed by the Nazi regime. Of the 210 priests active in the separated borderland parts of the diocese of České Budějovice in 1939-1945 three perished in the concentration camp of Dachau, five others survived imprisonment in concentration camps, 16 priests were obliged to leave their parishes because they received a ban of residence there, or in the whole Sudetenland, and 14 priests were investigated by the Gestapo and mostly sentenced to pay a fine. In connection with the topic of this paper I must also mention the figure of the saintly P. Engelmar Hubert Unzeitig, provisor in Glöckelberg. He was arrested by the Gestapo on $1^{\text {st }}$ October 1940 because he condemned the expulsion and genocide of the Jews, both while teaching at school and from the pulpit. He arrived at the concentration camp in Dachau on $3^{\text {rd }}$ June 1941. There he volunteered to nurse typhus patients and died on $2^{\text {nd }}$ March 1945 with the nickname 'Angel of Dachau'. ${ }^{24}$

\section{Refugeeism at the end of the war}

For a great many people the end of WWII meant liberation from the yoke of Nazism, oppression and subjection. Many refugees were slowly returning home. But there were also those who were condemned to refugeeism or exile as a result of endorsing the principle of collective guilt. On $19^{\text {th }}$

22 Josef BENEŠ, Kaine, kde je tvůj bratr?, pp. 74-78.

23 Cf. Martin WEIS, Osudy katolické církve na jihu Čech v období Protektorátu Čechy a Morava, pp. 63-70.

24 Ibid. 
May 1945 President Dr. Edvard Beneš issued a decree on confiscating the property of Germans and Hungarians, and on $2^{\text {nd }}$ August 1945 a decree on abrogating Czech state citizenship of Germans and Hungarians, whereby he began to fulfil the conclusions of the negotiations concerning the expulsion of three million Germans from Czechoslovakia. From the territory of diocese of České Budějovické 110 transports were sent to Germany with altogether 127,501 Germans. Of course, the German priests of the diocese were leaving with their parishioners. 71 priests transferred to German dioceses and 16 priests transferred to Austrian dioceses, so altogether 87 diocesan priests of German nationality left the diocese of České Budějovice as part of the expulsion. Most diocesan priests went to the dioceses Passau (28), Regensburg (20), Rottenburg (8) and Linz (8). Five priests went to S. Pölten, three priests to Vienna and Freiburg, two priests went to Augsburg, Bamberg, Mainz and Munich, and one to Eichstätt, Fulda, Limburg and Würzburg. It may be asked whether a priest did not become a victim of wild expulsions. According to the research of Emil Valasek, based on rigorous study of the preserved archive resources, this was not the case. $^{25}$

In connection with the expulsion of Germans to Germany the official bulletins of the diocese of České Budějovice published several important documents. The first one, published by the Land National Committee in Prague, deals with ecclesial rites in internment and collection camps. A priest, in whose district such a camp was located, was allowed to perform only the necessary rites for the interned persons, quiet ones, without sermons 'with respect to the nature of the matter and to the milieu'. ${ }^{26}$

The second significant document is the circular letter of the Land National Committee in Prague of $9^{\text {th }}$ July 1946 dealing with the expulsion of German priests and providing for the vacant parishes, which was published unabridged in the official diocesan bulletin of July 1946 . The circular letter stated that the government presidium at its $33^{\text {rd }}$ session of $14^{\text {th }}$ May 1946 permitted the expelled German priests to take not only the previously granted limit of $50 \mathrm{~kg}$ of personal baggage, but $100 \mathrm{~kg}$ or even more, so that they could take the personal belongings necessary to perform their vocation, i.e., the priestly garment, vestments of the mass, the laundry, the breviary, the missal, etc., provided that these objects are their personal property, not property of the parish, and that they are not made of precious metals. ${ }^{27}$

On $28^{\text {th }}$ August 1945 Pope Pius XII published a message on the $600^{\text {th }}$ anniversary of the birth of St. John of Nepomuk, which became the main guideline for the post-war renewal of our country in the spiritual sphere. In his message Pope Pius XII first recalled the tragic consequences of the war and then introduced the image of St. John of Nepomuk as the exemplar for the spiritual regeneration of the nation affected by the war. The Pope appealed first of all for the need for peace grounded in justice and love. He warned against outbursts of passionate hatred and desire for revenge, called for true freedom based on virtues and respect to God and warned against unbridled licentiousness and tyranny concealed beneath the mask of false freedom. This papal message was

25 Cf. Catalogus saecularis et regularis cleri dioeceseos Bohemo-Budvicensis 1948 and the personalia section of the official diocesan bulletin of 1945-1948. It is also possible to find more detailed information in the priestly register. On the expulsion of German priests see also the erudite monograph Emil VALASEK, Der Kampfgegen die Priester im Sudetenland 1938 bis 1945. In his monograph he lists in detail all the German priests expelled from the diocese of České Budějovice, including their personal data and brief biographies. According to this source no German priest fell victim to lynching or died in one of the so-called wild expulsions. But it must be admitted that some German priests in internment camps before the expulsion found the forced labour they were subjected to to be hard.

26 ACEB 1946, no. 2, p. 9.

27 ACEB 1946 , no. 7 b, July $26^{\text {th }}, 1946$, p. 33. 
followed in content by the first common pastoral letter of the episcopate of the Czech Republic, and was devoted to the most pressing contemporary issues of the Catholic Church in Czechoslovakia. In their pastoral letter the ordinaries first of all pointed out the dangerous growth of neo-pagan thought and the contemporary crisis of family life. They appealed for a greater use of the supernatural means of salvation, and placed an emphasis on Christian schooling, social reforms, more intense care of the youth and building up the lay apostolate. Quoting the words of Pope Pius's message cited above they were also calling attention to the relationship towards members of other nationalities, which was to be based on justice and love: 'How to behave towards members of other nationalities. The Holy Father's command in his letter to us holds: "The exercise of justice is not to transgress the limits of law and justice. Is it not true victory when we are overpowered by justice, overpowered by love? Let not the innocent be punished with the guilty, and when the guilty are punished let it not be done over the correct measure, so that there would be violence in sentencing the guilty, violence worth condemning, and, if seeds of resentment are sown everywhere, the nation would suffer harm in its innermost bonding. Let love be exercised in your private and public action as a companion to justice, as it is a noble token and the infallible mark of Christians." When we suffered, it was honourable for us and it is our glory, if we committed injustice, it would be a guilt before God and a blemish before people, and [the partners] abroad would not forget it. We must not be stained by even a shadow of the cruelty of the concentration camps, because history is sharp-eyed and in later years would denounce each misdemeanour as it now denounces the cruelty of the camps in Dachau, Auschwitz, and others. ${ }^{28}$

The issue of the often desperate fates of German priests as prisoners or refugees is also documented by the correspondence in the episcopal archive. There is the letter of P. Kroiher, former senator and clergyman from Ledenice, to the episcopal consistory in České Budějovice, in which he describes not only the heavy damage done to the borderland town of České Velenice by air raids, but also the burdensome situation of the German priest living there: 'Ledenice on $2^{\text {nd }}$ June 1945, Most reverend episcopal consistory! A former homesteader from Velenice has written to me of the church there: In this terrible rubble our church remained almost intact as if by miracle, only the windows are broken. A single window with the painting of blessed Agnes, which is a part of the main altar, has remained fully undisturbed. The church's interior is also fully preserved. Around the church in the park there is one crater next to another, at least 20 holes. The houses around are almost totally destroyed, the church and parish house remained as if by miracle with the exception of minor damage that can easily be repaired. The parish priest there, a very kind gentleman, begged me that you kindly intervene at the episcopal consistory, that a Czech clergyman be appointed there as soon as possible. He literally told me that he does not want to leave the church and will stay until a Czech parish priest comes, to whom he wants to hand everything over properly and in order, but I received the impression that he is probably afraid to stay there alone since he doesn't speak Czech and must pray in German. That is literally written by Mr. Květoň, former president of the church association there, for whom upon expulsion from Velenice I procured a place in a cooperative in Bechyně and whose house is so damaged that he cannot return immediately. Reporting this and conveying the parish priest's request I note that I am at the same time writing to Czech acquaintances to be patient and not grumble and not make the heart of a man of good will heavy, for the times are not like they used to be fifty years ago when there was a surplus of priests...29

28 Cf. ACEB 1945, no. 12, pp. 39-41.

29 SRA Třeboň, fond EA, carton no. 958, signatura I - E - 4, registry 1903-1945, folder 1945, original letter of $2^{\text {nd }}$ June 1945 , without a draft of reply. 
Another archive document of November 1945 depicts the desperate situation of a priest of the diocese of České Budějovice, who was conscripted as a Sudetenland German and when the war came to an end was in a detention camp: 'Brno - Slatina on $21^{\text {st }}$ November 1945 To the reverend episcopal consistory in České Budějovice. I am a priest of the diocese of České Budějovice, ordained in 1938, and I report that I have returned from Russian captivity and that I am in the detention camp in Brno - Slatina. Until 1940 I was chaplain in Vimperk, from March till October I was subsidiary in Reischachu near Alt Töting diecesis Passoviensis. On $7^{\text {th }}$ October $1940 \mathrm{I}$ became a sanitary soldier in the Reich army, and in 1943 assistant and military chaplain under the military parish priest in lazaret 1/606. With this lazaret and parish priest I came into Russian captivity on $23^{\text {rd }}$ August 1944 . On $1^{\text {st }}$ September the red army released me from captivity as I was ill. Despite that I am now held in the detention camp in Brno - Slatina for reasons unknown to me. The healthcare and dietary conditions in this camp are insufficient. Since it is a work camp I am forced frequently also to perform tasks unsuitable for the priestly state. I especially feel burdened by this detention because I never was a member of the NSDAP or other units. As a consequence of my vocation I was always antifascist. To prove this I offer the testimony of my former superior reverend prelate Dominik Brünner, dean emeritus in Vimperk, and my uncle Dr. Václav Houschka. Concerning the years of my study in 1933-1938 I mention the reverend rector Karel Reban. I therefore beg respectfully, that the rev. consistory request my dismissal and return home from the land headquarters of military detention camps in Brno. Josef Meisetschläger, priest. ${ }^{30}$

Another document is a note of the Dean's Office in Tábor, in which the author asks for instructions regarding what to do in the matter of Catholic priests of German dioceses, who are in the detention camp there as soldiers of Wehrmacht medical units. It is highly noteworthy that the local Red Army officer wanted to set these priests free, if some official church authority takes charge of them: 'Most reverend capitol consistory in Budějovice. In Tábor there are large camps of prisoners, among whom there are 40 Cathol. Priests from the Reich. They are lower officers with the medics and in offices and four as divisionpfarrer. They would like to be released to their places of work. Our military headquarters has no objections to the release, but the Red Army headquarters requests the consent of some most reverend bishop to take them as priests. I know there will be more such cases. I promised to make an enquiry regarding how they could be released from captivity, go to their workplaces or could stay free in some parishes for the time being. Tábor, $22^{\text {nd }}$ May 1945, Jaroslav Šebesta, dean. ${ }^{31}$ The Tábor dean Jaroslav Šebesta received a fairly curt and negative reply to this request saying that a German diocese must take care of Germans: 'To the reverend dean's office in Tábor. To the enquiry of 22/5 1945 no. 415 we reply: No ordinariate here can take the priests, because they are of German nationality. They must all appeal to their respective ordinariates, or some German ordinariate. ${ }^{32}$

\section{Conclusion}

This study focused on the issue of refugeeism from the viewpoint of the Catholic clergy of the diocese of České Budějovice, based on archive materials from the episcopal archive. World War II brought great suffering to many millions of humans: death on the battlefields as well as in the hinterland, the

30 SRA Třeboň, fond EA, carton no. 996, folder persecution during the war - letters concerning German clergymen after the end of the war, original signed, without a reply on the reverse of the request.

31 Ibid, original signed, on reverse there is a draft of the reply of the episcopal consistory.

$32 \mathrm{Ibid}$, a draft of the reply of the episcopal consistory on the reverse of the preceding request. 
unheard of brutalities of concentration camps, millions of refugees who had lost their homes and frequently also their loved ones. The study engages archive materials to show how this situation was experienced by the Catholic clergy in the South Bohemian region at the time.

To conclude allow me to quote words that still have a bearing on the burgeoning issue of refugeeism, although they were spoken more than seven decades ago: 'May the suffering of our time bring an end to suffering forever. Only then will all those immense sacrifices that we, the Germans of the Sudetenland, have to bring and that were to a great extent brought also by the Czechs, have some meaning. Only then will they have served the highest ideal of humanity - permanent and honest peace. ${ }^{33}$

\title{
World War II and the Issue of Refugeeism Focusing on the Diocese of České Budějovice in Light of Archive Materials from the Episcopal Archive
}

\begin{abstract}
World War II brought incomparable suffering to many millions of humans. It is impossible to calculate how many people were forced to leave their homes by the military operations or decisions of statesmen and were either forcibly deported or preferred to emigrate. This study recalls the issue of refugeeism associated with this tragic segment of human history from a specific viewpoint, viz. refugeeism as part of the history of the diocese of České Budějovice from 1938 up to 1947 in light of archive materials from the episcopal archive. It engages authentic documents to show how the issue of refugeeism was perceived and frequently also personally experienced by Catholic clergymen of the diocese of České Budějovice at the time.
\end{abstract}

Keywords: church history, Nazi regime, refugeeism, World War II, diocese of České Budějovice

\section{Author contact}

\section{Prof. Dr. Martin Weis}

University of South Bohemia, České Budějovice

Faculty of Theology, Department of Theological Disciplines

Kněžská 8, 37001 České Budějovice

weis@tf.jcu.cz

33 Last speech of Hans Krebs, a German MP condemned to death in Prague on 15 th January 1947. Milan SLÁDEK, Němci v Čechách, Pragma: Praha, 2002, pp. 151-153. 